\title{
PENGARUH LATIHAN FISIK AEROBIK TERHADAP WARNA DAN KEJERNIHAN URIN PADA PENDERITA HIPERTENSI
}

\section{EFFECT OF AEROBIC PHYSICAL EXERCISE ON URIN COLORS AND CLARITY IN HYPERTENSION PATIENTS}

\author{
Velly Fitri Dahlika ${ }^{1}$, Nurna Ningsih ${ }^{1}$, Rostika Flora $^{1}$, Lukman $^{2}$ \\ ${ }^{1}$ Bagian Keperawatan Fakultas Kedokteran Universitas Sriwijaya, Sumatera Selatan, Indonesia \\ ${ }^{2}$ Poltekkes Kemenkes Palembang, Sumatera Selatan, Indonesia \\ (penulis korespondensi:nurna_ningsih.nawawi@fk.unsri.ac.id)
}

Info Artikel: Diterima: 06 Januari 2020

Revisi: 26 Maret 2020

Disetujui: 03 Mei 2020

\begin{abstract}
ABSTRAK
Latar Belakang: Salah satu cara mengontrol tekanan darah oleh penderita hipertensi ini adalah latihan fisik aerobik. Latihan aktivitas fisik aerobik melibatkan kontraksi kelompok otot besar lengan dan kaki, dan menggunakan oksigen untuk membantu membakar lemak sebagai sumber bahan bakar utama untuk daya aktivitas. Penelitian ini bertujuan untuk mengetahui perbandingan warna dan kejernihan urin sebelum dan sesudah latihan fisik aerobik pada penderita hipertensi.

Metode: Penelitian ini adalah pre eksperimental dengan rancangan one group pre-post design, dilakukan intervensi berjalan kaki cepat sejauh $2,25 \mathrm{~km}$ dalam waktu 30 menit di wilayah kerja Puskesmas Gandus Kota Palembang pada tahun 2014. Besar sampel berjumlah 20 responden, pengukuran warna dan kejernihan urin dilakukan di laboratorium. Analisis statistik menggunakan uji pair t test.
\end{abstract}

Hasil: Sebagian besar responden berusia antara 46 - 47 tahun sebanyak $75 \%$, perempuan $75 \%$, dehidrasi ringan $30 \%$. Warna urin sebelum dan setelah aerobik berwarna kuning 90\%, setelah $85 \%$, sementara untuk kejernihan 5\% yang mengalami perubahan dari agak keruh menjadi keruh. Hasil uji statistik menunjukkan tidak ada perbedaan yang bermakna antara warna $(p=0,157)$ dan kejernihan urin $(\mathrm{p}=0,317)$ sebelum dan sesudah latihan fisik aerobik.

Kesimpulan: Latihan fisik aerobik dengan cara berjalan kaki cepat tidak mempengaruhi warna dan kejernihan urin penderita hipertensi. Oleh karena itu, perlu dilakukan penelitian lebih lanjut untuk memastikan pengaruh latihan fisik aerobik, menggunakan kelompok kontrol.

Kata kunci : Hipertensi, latihan fisik aerobik, warna dan kejernihan urin

\begin{abstract}
Background: One way to control blood pressure that can be done by people with hypertension is aerobic exercise. Aerobic physical activity training involves contracting large muscle groups of arms and legs, and using oxygen to help burn fat as the main fuel source for activity power. This study aims to determine the categories of color and clarity of urine before and after aerobic physical exercise in patients with hypertension.

Methods: This research method is pre-experimental with one group pre-post design, the intervention runs fast as far as $2.25 \mathrm{~km}$ in 30 minutes in the work area of the Gandus Health Center, Palembang city in 2014. The sample size was 20 respondents, the measurement of color and clarity of urine is done by experts in the laboratory. Analyze of statistic by pair t test.

Results:Most respondents aged between 46-47 years were $75 \%$, women $75 \%$, mild dehydration $30 \%$. Yellow urine before and after aerobics is $90 \%$ yellow, after $85 \%$, while $5 \%$ urine clarity has changed from slightly cloudy to cloudy. Statistical test results found no significant differences between color ( $p$ $=0.157)$ and urinary clarity $(p=0.317)$ before and after aerobic physical exercise.

Conclusion:Aerobic physical exercise with fast walking does not affect the color and clarity of urine in people with hypertension. Future researchers are expected to conduct a similar study using a control group.
\end{abstract}

Keywords : Hypertension, aerobic physical exercise, color and urine clarity 


\section{PENDAHULUAN}

Tekanan darah merupakan faktor yang amat penting pada sistem sirkulasi. Peningkatan atau penurunan tekanan darah akan mempengaruhi homeostatsis di dalam tubuh. Jika sirkulasi darah menjadi tidak memadai lagi maka terjadilah gangguan pada sistem transportasi oksigen, karbondioksida, dan hasilhasil metabolisme lainnya. Di lain pihak fungsi organ-organ tubuh akan mengalami gangguan seperti gangguan pada proses pembentukan air seni di dalam ginjal ataupun pembentukan cairan cerebrospinalis dan lainnya.

Penyakit hipertensi tidak bisa sembuh secara total namun penanganan hipertensi ini bisa dilakukan secara efektif bila penderita mengikuti program penanganan dengan benar. Salah satu terapi yang dapat dilakukan yaitu latihan fisik aerobik misalnya jalan kaki, renang, senam dan lain-lain. ${ }^{1}$

Latihan aktivitas fisik aerobik melibatkan kontraksi kelompok otot besar lengan dan kaki, dan menggunakan oksigen untuk membantu membakar lemak sebagai sumber bahan bakar utama untuk daya aktivitas. ${ }^{2}$ Latihan fisik aerobik seperti jalan kaki pada penderita hipertensi memang sangat dianjurkan terutama pada penderita tahap 1 hipertensi yang berusia tengah baya tanpa keluhan yang berarti karena aktivitas aerobik menimbulkan efek seperti beta blocker yang dapat menenangkan sistem saraf simpatikus dan melambatkan denyut jantung.

Selain itu aktivitas aerobik juga dapat menurunkan jumlah keluaran noradrenalin dan hormon - hormon lainnya yang menyebabkan stres sehingga menyebabkan pembuluhpembuluh darah menciut dan menaikan tekanan darah. $^{3}$

Latihan aerobik dapat menurunkan tekanan darah karena latihan itu dapat merilekskan pembuluh-pembuluh darah. Lamakelamaan, latihan olahraga dapat melemaskan pembuluhpembuluh darah, sehingga tekanan darah menurun, sama halnya dengan melebarnya pipa air akan menurunkan tekanan air. Latihan olahraga juga dapat menyebabkan aktivitas saraf, reseptor hormon, dan produksi hormon-hormon tertentu menurun. Bagi penderita hipertensi latihan aerobik dengan intensitas ringan dan bersifat intermitten tetap cukup aman dilakukan setiap saat. ${ }^{4}$

Pelaksanaan latihan fisik aerobik pada penderita hipertensi ini memiliki beberapa syarat yang perlu dipenuhi sebelum melakukan aktivitas fisik seperti tekanan darah sistolik tidak melebihi $160 \mathrm{mmHg}$ dan tekanan diastolik tidak melebihi $100 \mathrm{mmHg}$, sebelum melakukan latihan fisik aerobik obat yang sedang diminum tetap diteruskan, usia penderita hipertensi dan tingkat aktivitas sehari-harinya. Selain itu latihan fisik aerobik ini mempunyai dampak yang sangat serius bagi tubuh apabila tidak disertai dengan pengaturan minum selama melakukan aktivitas fisik aerobik ini yaitu dehidrasi ringan sampai berat. ${ }^{3}$

Latihan fisik dapat mengakibatkan terjadinya pengeluaran panas yang berlebihan melalui keringat. Keringat terdiri dari ion natrium, kalium dan klorida Apabila terjadi pengeluaran keringat yang berlebihan dapat mengakibatkan terjadinya dehidrasi. ${ }^{5}$ Pada orang yang mengalami dehidrasi dapat berpengaruh yang signifikan bagi tubuh, hal ini terjadi pada kehilangan cairan $2 \%$ dari total berat badan dapat memberikan efek penurunan performa tubuh menjadi lemas, lemah dan berkurangnya konsentrasi. Saat dehidrasi mencapai $4 \%$, menyebabkan kapasitas kerja otot menjadi menurun, 5\% tubuh mengalami heat exhaustion (keletihan yang dialami tubuh karena kehilangan cairan), $7 \%$ kehilangan cairan dapat menyebabkan terjadinya halusinasi otak dan kerja menjadi tidak terkontrol.

Kehilangan cairan sebesar $10 \%$ terjadi heat stroke (kondisi suhu tubuh terlalu tinggi dan kerja organ tubuh menjadi kacau). ${ }^{6}$ Seseorang yang mengalami dehidrasi dapat dilihat lewat warna urin dan kejernihan urin yang dikeluarkan. Hal inilah yang dapat menentukan seseorang mengalami dehidrasi akut atau tidak. Apabila warna urin jernih, ini menunjukkan status hidrasi tubuh seseorang baik. Sebaliknya bila warna urin menjadi kuning tua dan pekat. $^{7}$ Oleh karena itu perlu dilakukan penelitian lebih lanjut untuk mengetahui perbedaan warna dan kejernihan urin sebelum dan sesudah latihan fisik aerobik pada penderita hipertensi di Wilayah kerja Puskesmas Gandus Kota Palembang. 


\section{METODE}

Penelitian ini merupakan penelitian preeksperimental kuantitatif yang diberi perlakuan berupa latihan fisik aerobik menggunakan one group pre-post tes design. ${ }^{8,9,10}$ Pengambilan data dilaksanakan pada tanggal 14 April sampai dengan 23 Agustus 2014.

Intervensi latihan fisik aerobik dilaksanakan pada tanggal 8 Oktober 2014, bertempat di Wilayah Kerja Puskesmas Gandus Kota Palembang. Jumlah penderita hipertensi di wilayah kerja Puskesmas Gandus Kota

\section{HASIL}

Berdasarkan tabel 1 sebagian besar responden berusia antara $46-47$ tahun
Palembang pada bulan Januari sampai Agustus 2014 berjumlah 1958 orang. Jumlah sampel sebanyak 20 orang diambil dengan teknik purposive sampling. Sebelum intervensi, tidak ada anjuran khusus kepada responden misalnya dengan minum yang banyak, namun responden hanya melakukan menurut kebiasaan saja. Pengukuran status hidrasi, warna dan kejernihan urin dilakukan oleh petugas di Laboratorium. Analisis statistik menggunakan uji pair $t$ test. $^{11,12}$

Tabel 1. Karakteristik Responden $(n=20)$

\begin{tabular}{lcc}
\hline Karakteristik & Jumlah & Persentase (\%) \\
\hline Umur (tahun) & & \\
$45-47$ & 15 & 75 \\
$48-50$ & 5 & 25 \\
Jenis Kelamin & 5 & 25 \\
$\quad$ Pria & 15 & 75 \\
$\quad$ Perempuan & & \\
Status Hidrasi sesudah latihan & & 70 \\
fisik aerobik & 14 & 30 \\
$\quad$ Tidak dehidrasi & 6 & - \\
Dehidrasi ringan & - & - \\
$\quad$ Dehidrasi sedang & - & \\
Dehidrasi berat & &
\end{tabular}

Tabel 2. Distribusi warna dan kejernihan urin $(n=20)$

\begin{tabular}{lcccc}
\hline \multirow{2}{*}{ Urin } & \multicolumn{2}{c}{ Sebelum } & \multicolumn{2}{c}{ Sesudah } \\
\cline { 2 - 5 } & Frekuensi & Persentase (\%) & Frekuensi & $\begin{array}{c}\text { Persentase } \\
(\%)\end{array}$ \\
\hline Warna & & & & 5 \\
$\quad$ Tidak berwarna & - & - & 1 & 10 \\
$\quad$ Kuning muda & 2 & 10 & 2 & 85 \\
$\quad$ Kuning & 18 & 90 & 17 & 10 \\
Kejernihan & & & & 75 \\
$\quad$ Jernih & 2 & 10 & 2 & 15 \\
Agak keruh & 16 & 80 & 15 & \\
$\quad$ Keruh & 2 & 10 & 3 & \\
\hline
\end{tabular}

Tabel 2 menunjukkan bahwa, sebelum latihan fisik aerobik $90 \%$ warna urin berwarna kuning dan setelah latihan fisik aerobik sebanyak 15 orang (75\%), perempuan $75 \%$, dehidrasi ringan $6(30 \%)$. 
responden (5\%) yang terjadi perubahan kejernihan menjadi keruh.

Tabel 3. Perbedaan Warna dan Kejernihan Urin Sebelum dan Setelah Latihan Fisik Aerobik $(n=20)$

\begin{tabular}{lccccc}
\hline Urin & \multicolumn{2}{c}{ Sebelum } & \multicolumn{2}{c}{ Setelah } & p value \\
& Frekuensi & $\begin{array}{c}\text { Persentase } \\
(\boldsymbol{\%})\end{array}$ & Frekuensi & $\begin{array}{c}\text { Persentase } \\
(\boldsymbol{\%})\end{array}$ & \\
\hline Warna & - & & & 5 & \\
$\quad$ Tidak berwarna & - & 10 & 2 & 10 & 0,157 \\
$\quad$ Kuning muda & 2 & 90 & 17 & 85 & \\
$\quad \begin{array}{l}\text { Kuning } \\
\text { Kejernihan }\end{array}$ & 18 & & & & \\
$\quad$ Jernih & 2 & 10 & 2 & 10 & 0,317 \\
Agak keruh & 16 & 80 & 15 & 75 & \\
Keruh & 2 & 10 & 3 & 15 & \\
\hline
\end{tabular}

Pada Tabel 3 menunjukkan bahwa hasil uji statistik menggunakan pair $t$ test didapatkan pengaruh latihan fisik aerobik terhadap warna

\section{PEMBAHASAN}

Penelitian ini mendapatkan latihan fisik aerobik tidak berpengaruh terhadap warna dan kejernihan urin pada penderita hipertensi di Puskesmas Gandus Kota Palembang. Sesuai penelitian seluruh responden tidak mengalami perubahan kejernihan urin setelah melakukan latihan fisik pada kelompok maksimal dan submaksimal, seluruh urin responden berada pada tingkat kejernihan yang jernih. ${ }^{13} \mathrm{Hal}$ tersebut dimungkinkan karena sebagian besar responden sudah terbiasa melakukan kegiatan sehari-hari seperti berjalan kaki dan sebagian responden merupakan buruh pabrik yang biasa berkerja dari pagi hari sampai sore hari.

Sebagian besar responden tidak mengalami dehidrasi disebabkan berbagai faktor, seperti jenis kelamin, umur dan jumlah lemak tubuh, dan makanan yang dikonsumsi oleh responden. Selain itu, perubahan warna urin pada responden penelitian tidak terlalu terlihat karena tingkat dehidrasi yang dialami oleh responden berada pada tingkat ringan sehingga perubahan karakteristik urin tidak begitu terlihat.

Jumlah urin normal yang dihasilkan tubuh rata - rata 1 - 2 liter setiap harinya tetapi perbedaan jumlah urin sesuai cairan yang dimasukkan, jika banyak mengkonsumsi protein maka akan diperlukan banyak cairan untuk melarutkan ureanya, sehingga urin yang dikeluarkan jumlahnya sedikit dan menjadi pekat. $^{14,15}$ Kekeruhan biasanya terjadi karena urin $\mathrm{p}=0,157$ dan terhadap kejernihan urin $\mathrm{p}=0,317$.

kristalisasi atau pengendapan asam urat (dalam urin asam) atau fosfat (dalam urin basa). Kekeruhan juga bisa disebabkan oleh kelebihan protein dalam urin. Kelainan pada kejernihan urin juga dapat mengindikasikan kemungkinan adanya infeksi, dehidrasi, darah dalam urin (hematuria), penyakit hati, kerusakan otot atau eritrosit dalam tubuh. ${ }^{16,17}$

Semakin tinggi umur seseorang semakin tinggi tekanan darahnya, jadi orang yang lebih tua cenderung mempunyai tekanan darah yang tinggi dari orang yang berumur lebih muda. ${ }^{18,19}$ Penderita hipertensi lebih banyak diderita oleh perempuan yang berumur 50 tahun ke atas, padahal jumlah penderia hipertensi pada umur muda lebih banyak terjadi pada laki- laki. Prevalensi hipertensi pada laki-laki 59,1\% dan perempuan $61,0 \%$. Sesuai penelitian yang di Kecamatan Kemuning Kota Palembang bahwa perempuan lebih berisiko mengalami hipertensi dibandingkan dengan pria. ${ }^{20}$

Pengukuran status hidrasi dilakukan oleh petugas laboratorium, dengan hasil sebagian besar responden tidak mengalami dehidrasi setelah latihan fisik aerobik. Dehidrasi ringan dapat terjadi akibat peningkatan intensitas latihan dan peningkatan suhu tubuh selama latihan. Dehidrasi dapat mempengaruhi performa seseorang apabila kehilangan $2 \%$ dari berat badannya namun tidak berpengaruh jika seseorang hanya kehilangan $1 \%$ dari berat badannya. ${ }^{21,22}$ 


\section{KESIMPULAN DAN SARAN}

Latihan fisik aerobik tidak mempengaruhi warna dan kejernihan urin penderita hipertensi, namun demikian latihan fisik aerobik dapat membantu mengontrol tekanan darah. Perlu

\section{UCAPAN TERIMA KASIH}

Kami ucapkan terima kasih kepada Bagian Keperawatan Fakultas Kedokteran Universitas

\section{DAFTAR PUSTAKA}

1. Go AS, et al., 2013. An Effective Approach to High Blood Pressure Control: a science advisory from the American Heart Association, the American College of Cardiology, and the Centers for Disease Control and Prevention, Hypertension.

2. Palar CM., Wongkar D., Ticoalu SHR., 2015. Manfaat Latihan Olahraga Aerobik Terhadap Kebugaran Fisik Manusia.; Jurnal e-Biomedik (eBm), 3(1): 316-21

3. Prasetyo Y., 2004. Olahraga bagi Penderita Hipertensi. Universitas Negeri Yogyakarta. 2011.

4. Sloane, 2014. Anatomi Fisiologi Untuk Pemula. Jakarta : EGC

5. Irawan MA., 2007. Konsumsi Cairan dan Olahraga. Available from: http://www.pssplab.com/journal/01.pdf. diakses 5 September 2014

6. Rismayanthi C., 2009. Bahan ajar gizi olahraga. "Dehidrasi". http//: www.uny.ac.id. diakses tanggal 18 September 2014

7. Murray B., 2007. Hydration and physical performance. Journal of the American College of Nutrition; 26 (Supplement 5): 542S.

8. Arikunto. 2013. Prosedur Penelitian Suatu Pendekatan Praktik. Jakarta: Rineka Cipta.

9. Nursalam. 2013. Metodelogi Penelitian: Pendekatan Praktis (Edisi 3). Jakarta: Salemba Medika.

10. Andarmoyo. 2013. Pengolahan data menggunakan analisis univariat dan bivariat.

11. Hastono. 2001. Analisa Data, Jakarta: FKM Universitas Indonesia.

12. Dahlan. S., 2011. Statistik untuk Kedokteran dan Kesehatan (5 ed). Jakarta: Salemba Medika. dilakukan penelitian lanjutan terkait latihan fisik aerobik menggunakan kelompok kontrol dengan jumlah responden yang lebih besar.

Sriwijaya yang telah memfasilitasi kegiatan ini dalam bentuk fasilitasi administrasi.

13. Suprida. 2014. Perbandingan Tingkat Dehidrasi, Kadar Anti Diuretic Hormone $(\mathrm{ADH})$ Dan Karakteristik Urine Pada Aktivitas Fisik Maksimal Dan Submaksimal. Jurnal Kesehatan Poltekkes Palembang; 2(14).

14. Pearce E., 2009. Anatomi Fisiologi. Jakarta: PT Gramedia Pustaka Utama.

15. Watulingas I., Rampengan JV., Polii H., 2013. Pengaruh Latihan Fisik Aerobik Terhadap Vo2 Max Pada Mahasiswa Pria Dengan Berat Badan Lebih (Overweight). Jurnal e-Biomedik (eBM), 1 (2); 1064 1068

16. Sherwood L., 2012. Keseimbangan cairan dan asam-basa. In: Fisiologi Manusia dari Sel Ke Sistem (Edisi 6). Pendit BU Alih bahasa. Jakarta: EGC.

17. Kohanpour MA., Sanavi S., Peeri M., Zare AH., \& Mirsepasi M., 2012. Effect of Submaximal Aerobic Exercise in Hypoxic Conditions on Proteinuria and Hematuria in Physically Trained Young Men. Iranian Journal of Kidney Diseases, 6(3); 192 197.

18. Naid T., Mangarengi F., Nursina. 2013. Gambaran Urinalisa Pasien Hipertensi Rawat Inap Dan Rawat Jalan Di Rumah Sakit Labuang Baji. Jurnal As-Syifaa, 5 (1): 103-111.

19. Rahajeng E., Tuminah S. 2009. Prevalensi Hipertensi dan Determinannya di Indonesia. Majalah Kedokteran Indononesia, 59 (12): $580-587$.

20. Maksuk M. Analisis Faktor Risiko Penyakit Hipertensi Pada Masyarakat Di Kecamatan Kemuning Kota Palembang Tahun 2012. JPP (Jurnal Kesehat Poltekkes Palembang). 2012;1(10). 
(JPP) Jurnal Kesehatan Poltekkes Palembang

Vol. 15, No. 1, Juni 2020, eISSN 2654-3427

DOI: 10.36086/jpp.v15i1.423

21. Kenney WL., Wilmore JH., Costill DL., 2015. Physiology of Sport and Exercise 6th Edition.

22. Leksana E., 2015. Strategi Terapi Cairan pada Dehidrasi. CDK-224. 42(1); 70 - 73. 